\title{
Potensi Ekstrak Etanol Herba Apu-Apu (Pistia stratiotes) dan Fraksi-Fraksinya Sebagai Antioksidan Dengan Metode DPPH
}

\section{Potency of Ethanolic Extract of Pistia stratiotes Herbs and Its Fractions as Antioxidants using DPPH Method}

\author{
Dewi Dianasari", Irawati Firdiyansari \\ Fakultas Farmasi, Universitas Jember, Jember, Indonesia \\ *Email: dewi.dianasari@unej.ac.id
}

Received: 01 November 2019; Accepted: 26 Desember 2019; Published: 27 Desember 2019

\begin{abstract}
Abstrak
Radikal bebas berperan penting pada terjadinya kerusakan sel dan penyakit degeneratif seperti penyakit jantung koroner, stroke, penuaan dini dan lain-lain. Senyawa yang dapat menghambat radikal bebas yaitu antioksidan. Salah satu tumbuhan yang memiliki kandungan senyawa fenolik tinggi dan bisa menjadi sumber antioksidan alami yakni apu-apu atau Pistia stratiotes. Penelitian ini dilakukan untuk membuktikan secara ilmiah adanya aktivitas antioksidan dari ekstrak etanol herba apu-apu (Pistia stratiotes) dan fraksi-fraksinya dengan metode DPPH. Sampel yang digunakan berupa semua bagian apu-apu (herba apu-apu) yang didapatkan dari daerah Kecamatan Sumbersari, Kabupaten Jember. Pada penelitian ini digunakan metode DPPH dengan konsentrasi DPPH sebesar 0,1 mM, waktu inkubasi ekstrak etanol 40 menit, fraksi n- heksana 50 menit, fraksi etil asetat 45 menit, fraksi etanol- air 40 menit, vitamin C 35 menit dan diukur pada pada panjang gelombang $517 \mathrm{~nm}$. Hasil rata- rata aktivitas antioksidan $\left(\mathrm{IC}_{50}\right)$ yaitu ekstrak etanol herba apu-apu $16,675 \mu \mathrm{g} / \mathrm{mL} \pm 0,239$, fraksi n-heksana $29,915 \mu \mathrm{g} / \mathrm{mL} \pm 0,156$, fraksi etil asetat $11,875 \mu \mathrm{g} / \mathrm{mL} \pm 0,038$, fraksi etanol-air $9,090 \mu \mathrm{g} / \mathrm{mL} \pm 0,122$, dan vitamin $\mathrm{C} 3,263 \mu \mathrm{g} / \mathrm{mL} \pm 0,032$. Vitamin $\mathrm{C}$ sebagai kontrol positif memiliki aktivitas yang paling tinggi, sedangkan sampel apu-apu yang memiliki aktivitas antioksidan tertinggi yaitu fraksi etanol-air, dan yang terendah adalah fraksi n- heksana. Dari penelitian ini dapat disimpulkan bahwa ekstrak etanol herba apu-apu dan fraksi-fraksinya memiliki aktivitas antioksidan, yaitu dari yang tinggi ke rendah secara berurutan : fraksi etanol-air, fraksi etil asetat, ekstrak etanol herba apu-apu, fraksi n-heksana. Kata Kunci: apu-apu, DPPH, ekstrak, fraksi
\end{abstract}

\begin{abstract}
Free radicals play an important role in cell damage and degenerative diseases such as coronary heart disease, stroke, premature aging and others. Compounds that can inhibit free radicals are antioxidants. One of the plants that has a high phenolic compound and can be a source of natural antioxidants, apu-apu or Pistia stratiotes. This research was conducted to scientifically prove the antioxidant activity of the apu-apu herbal extract (Pistia stratiotes) and its fractions by the DPPH method. The sample used in the form of all parts apu-apu (арu-apu herb) obtained from the Sumbersari District, Jember Regency. In this study the DPPH method was used with a DPPH concentration of $0.1 \mathrm{mM}$, incubation time of ethanol extract 40 minutes, fraction of n-hexane 50 minutes, ethyl acetate fraction 45 minutes, ethanol-water fraction 40 minutes, vitamin C 35 minutes and measured at wavelength $517 \mathrm{~nm}$. The results of the average antioxidant activity (IC50) were apu-apu herbal extract $16.675 \mu \mathrm{g} / \mathrm{mL} \pm 0.239, n$-hexane fraction $29.915 \mu \mathrm{g} / \mathrm{mL} \pm 0.156$, ethyl acetate fraction $11.875 \mu \mathrm{g} / \mathrm{mL} \pm 0.038$, ethanol-water fraction $9.090 \mu \mathrm{g} / \mathrm{mL} \pm 0.156$, ethyl acetate fraction 11.875 $\mu \mathrm{g} / \mathrm{mL} \pm 0.038$, ethanol-water fraction $9.090 \mu \mathrm{g} / \mathrm{mL} \pm 0.156$, ethyl acetate fraction $11.875 \mu \mathrm{g} / \mathrm{mL} \pm 0.038$ $/ \mathrm{mL} \pm 0.122$, and vitamin $C 3.263 \mu \mathrm{g} / \mathrm{mL} \pm 0.032$. Vitamin $C$ as a positive control had the highest activity, whereas the apu-apu sample which had the highest antioxidant activity was the ethanol-water fraction, and the lowest was the n-hexane fraction. The conclusion of this study is apu-apu herbal ethanol extract and its fractions have antioxidant activity, from high to low sequentially: ethanol-water fraction, ethyl acetate fraction, apu-apu herbaceous fraction, $n$ - fraction hexane.
\end{abstract}

Keywords: DPPH,apu-apu, extract, fraction 


\section{PENDAHULUAN}

Radikal bebas berperan penting pada terjadinya kerusakan sel dan penyakit degeneratif seperti penyakit jantung koroner, stroke, penuaan dini dan lain-lain (Kumalaningsih, 2006). Radikal bebas umumnya merupakan senyawa reaktif yang memiliki elektron terluar tidak berpasangan. Sehingga senyawa ini cenderung memiliki kereaktifan tinggi yang menimbulkan reaksi berantai dengan sel penting di dalam tubuh (Badarinath et al. 2010). Senyawa yang dapat menghambat radikal bebas yaitu antioksidan. Senyawa ini memiliki struktur molekul yang dapat memberikan elektron (donor elektron) pada molekul radikal bebas sehingga dapat memutus reaksi berantai (Halliwell \& Gutteridge, 2000).

Dalam sistem biologis manusia, secara alami diproduksi senyawa antioksidan seperti enzim SOD (superoksida dismutase), glutathione, dan katalase. Senyawa tersebut dapat melindungi tubuh dari kerusakan jaringan oleh oksidasi reactive oxygen species (ROS), serta menghambat terjadinya peroksidasi lipid pada makanan. Ketersediaan antioksidan yang diproduksi secara alami oleh tubuh seringkali tidak mencukupi sehingga dibutuhkan asupan dari luar seperti antioksidan dari bahan alam dan sintetis. Namun menurut penelitian Ito et al. (1986), menyatakan bahwa penggunaan antioksidan sintetik dapat meningkatkan resiko karsinogenesis. Adapun antioksidan dari bahan alam seperti makanan dengan kandungan vitamin $\mathrm{E}, \mathrm{C}$, betakaroten maupun antioksidan fitokimia dari golongan fenol (Kumalaningsih, 2006).

Salah satu tumbuhan yang memiliki kandungan fenol yaitu Apu-apu (Pistia stratiotes) (Khare, 2005). Apu-apu sering dianggap gulma oleh petani. Namun tidak jarang digunakan sebagai penghias kolam oleh masyarakat. Kandungan dalam apu-apu yakni $92,9 \%$ air, $1,4 \%$ protein, $0, .3 \%$ lemak $2,6 \%$ karbohidrat, $0,9 \%$ serat kasar, $1,9 \%$ mineral. Selain itu tumbuhan apu-apu memiliki kandungan kimia seperti alkaloid, flavonoid, glikosida, vitamin, stigmasterol dan asam palmitat, vicenin, vitexin, orientin. Tanaman apu-apu memiliki aktivitas farmakologis sebagai analgesik, antiinflamasi, antipiretik, antioksidan, bronkodilator, diuretik, antigout (Kumar et al., 2011 dan Pallavi et al., 2011). Berdasarkan uraian di atas, maka dilakukan penelitian untuk membuktikan secara ilmiah adanya aktivitas antioksidan dari ekstrak etanol herba apu-apu (Pistia stratiotes) dan fraksi-fraksinya. Ekstrak etanol herba apu-apu akan difraksinasi untuk memisahkan kandungan metabolit sekunder berdasarkan kepolarannya, sehingga dapat dibandingkan aktivitas antioksidan ekstrak yang mengandung semua metabalit sekunder yang terkestraksi dengan fraksi-fraksinya yang hanya mengandung metabolit sekunder tertentu.

\section{METODE PENELITIAN}

\section{Alat}

Alat yang digunakan dalam penelitian ini adalah timbangan analitik (Santorius), vacuum rotary evaporator (Heidolph ), spektrofotometer UV-Vis (Hitachi U-1800), mikropipet $10-1000 \mu \mathrm{L}$ (Socorex), dan alatalat gelas (Pyrex Germany dan Iwaki).

Bahan

Bahan-bahan yang digunakan dalam penelitian ini adalah herba apu-apu (Pistia stratiotes), akuades; bahan kualitas p.a. E. Merck yaitu: etanol, metanol, n- heksana, etil asetat, bahan kualitas p.a. Sigma-Aldrich yaitu: DPPH (1,1difenil-pikrilhidrazil); vitamin C (PT. Brataco), natrium karbonat. Pembuatan Ekstrak Etanol Herba Apu-Apu Ekstraksi serbuk simplisia herba apu-apu (Pistia stratiotes) dengan metode maserasi dalam pelarut etanol 96\% (1:10), selama 3 hari. Maserat yang didapatkan diuapkan dengan rotavapour dan dikeringkan.

Fraksinasi

Proses fraksinasi menggunakan metode partisi cair-cair menggunakan pelarut etanol-air, nheksana, dan etil asetat. Masing-masing fraksi n-heksana, etil asetat dan fraksi etanol-air diuapkan hingga pekat. 
Pengujian Aktivitas Antioksidan dengan DPPH

Pengujian aktivitas antioksidan ekstrak etanol herba apu-apu (Pistia stratiotes) dengan DPPH dilakukan berdasarkan Molyneux (2004), dengan pembanding Vitamin C.

a. Penentuan Panjang Gelombang Serapan Maksimum DPPH

Larutan DPPH 0,1 mM sebanyak 1,5 mL dan 1,5 mL metanol sebagai baseline masingmasing dimasukkan ke dalam kuvet. Kemudian, larutan tersebut diukur pada panjang gelombang 400-800 $\mathrm{nm}$ dengan spektrofotometer UV-Vis.

b. Penentuan Waktu Inkubasi

Penentuan waktu inkubasi dilakukan dengan memipet $300 \mu \mathrm{L}$ larutan sampel dan vitamin C ditambahkan dengan $1200 \mu \mathrm{L}$ larutan DPPH 0,1 mM. Larutan diamati pada panjang gelombang maksimum mulai menit ke-0 sampai menit ke-60 selang 5 menit.

c. Pembuatan Larutan sampel

Larutan stok 2000 ppm dibuat dengan melarutkan $20 \mathrm{mg}$ ekstrak ke dalam $10 \mathrm{~mL}$ metanol (ditambah beberapa tetes DMSO jika sampel kurang larut dalam metanol). Kemudian, larutan diencerkan dengan memipet sejumlah tertentu larutan dan dimasukkan ke dalam labu ukur ditambahkan metanol, sehingga diperoleh beberapa konsentrasi larutan uji akhir.

d. Pembuatan Larutan Vitamin C

Vitamin $\mathrm{C}$ ditimbang $25 \mathrm{mg}$ dimasukkan ke dalam labu ukur $25 \mathrm{~mL}$ dan dilarutkan dengan metanol sampai batas volume sehingga konsentrasi vitamin $\mathrm{C}$ sebesar $1000 \mu \mathrm{g} / \mathrm{mL}$. Larutan dipipet 10, 20, 40, 50, 60, 80, 100 $\mu \mathrm{L}$ dan dimasukkan labu ukur $10 \mathrm{~mL}$, ditambahkan dengan metanol sampai tanda batas.

e. Penetapan Aktivitas Antioksidan Larutan Uji dan Vitamin C Masing-masing sampel dipipet sebanyak 0,375 $\mu \mathrm{L}$ ditambahkan $1,125 \mu \mathrm{L}$ larutan DPPH di dalam tabung reaksi, kemudian diinkubasi pada suhu ruang di dalam ruangan gelap (waktu inkubasi ekstrak etanol 40 menit, fraksi n- heksana 50 menit, fraksi etil asetat 45 menit, fraksi etanol- air 40 menit, vitamin C 35 menit). Sebagai kontrol positif, digunakan vitamin $\mathrm{C}$ yang juga diinkubasi dengan larutan DPPH dengan volume yang sama. Selanjutnya kadar serapan larutan setelah inkubasi ditentukan dengan spektrofotometri UV-Vis pada panjang gelombang maksimum.

Analisis Data

Perhitungan persen penghambatan sampel terhadap DPPH sesuai dengan persamaan 1.

$$
\begin{aligned}
& \text { \% Inhibisi DPPH } \\
& =\frac{\text { abs DPPH }- \text { abs larutan uji }}{\text { abs DPPH }} \times 100 \%
\end{aligned}
$$

Konsentrasi sampel dan persen inhibisinya diplot masing-masing pada sumbu $\mathrm{x}$ dan $\mathrm{y}$ pada persamaan regresi linear. Persamaan tersebut digunakan untuk menentukan nilai $\mathrm{IC}_{50}$ dari masing-masing sampel dinyatakan dengan nilai y sebesar 50 dan nilai $\mathrm{x}$ yang diperoleh sebagai $\mathrm{IC}_{50}$.

\section{HASIL DAN PEMBAHASAN}

Pada penelitian ini ekstrak herba apu-apu didapatkan dari metode dengan cara dingin yaitu maserasi (Depkes RI, 2000). Pelarut yang digunakan pada penelitian ini yaitu etanol 96\%. Etanol merupakan pelarut polar yang dapat menarik senyawa polar juga seperti senyawa fenol. Persen rendemen ekstrak etanol herba Apu-apu yaitu 12,5\%. Hasil persen rendemen dipengaruhi oleh jumlah senyawa yang telarut dalam dalam tanaman tersebut.

Ekstrak kental yang diperoleh selanjutnya dilakukan fraksinasi. Tujuan dilakukan fraksinasi yaitu untuk memisahkan senyawa-senyawa berdasarkan tingkat kepolarannya. Dalam penelitian ini metode fraksinasi yang digunakan yaitu metode partisi cair-cair menggunakan corong pisah. Proses fraksinasi dilakukan bertingkat dimulai dengan pelarut non polar ke semipolar kemudian ke pelarut polar. Hal tersebut dilakukan agar proses distribusi senyawa dapat bertahap sehingga senyawa dapat 
tertarik sempurna (Edawati, 2012). Rendemen proses fraksinasi dapat dilihat pada Tabel 1.

Tabel 1. Rendemen Fraksinasi Ekstrak Etanol Herba Apu-Apu

\begin{tabular}{cc}
\hline Jenis Fraksi & Rendemen $(\%)$ \\
\hline N-heksana & 33,3 \\
Etil asetat & 2,3 \\
Etanol-air & 48,6 \\
\hline
\end{tabular}

Dapat dilihat bahwa jenis pelarut mempengaruhi jumlah rendemen fraksi. Rendemen fraksi terbesar yaitu 48,6\% pada fraksi etanol air, hal ini terjadi dimungkinkan banyaknya senyawa herba apu-apu yang memiliki sifat polar sehingga banyak terditribusi pada fraksi polar. Rendemen fraksi terkecil yaitu 2,3\% pada fraksi etil asetat yang dimungkinkan senyawa yang bersifat semi polar sedikit. Tabel 2

Waktu inkubasi sampel dapat dilihat pada

Tabel 2. Waktu Inkubasi

\begin{tabular}{cc}
\hline Sampel & $\begin{array}{c}\text { Waktu Inkubasi } \\
\text { (Menit) }\end{array}$ \\
\hline Ekstrak Etanol & 40 \\
Fraksi N-heksana & 50 \\
Fraksi Etil asetat & 45 \\
Fraksi Etanol-air & 40 \\
Vitamin C & 35 \\
\hline
\end{tabular}

Berdasarkan hasil optimasi yang telah dilakukan, diperoleh panjang gelombang maksimum sebesar $517 \mathrm{~nm}$ untuk larutan DPPH yang berwarna ungu (violet). Hal ini telah sesuai dengan teoritis yang menyatakan bahwa panjang gelombang maksimum DPPH yaitu sebesar 515-520 nm..

Waktu optimum berlangsungnya reaksi DPPH dengan larutan uji yaitu 30 menit, namun waktu inkubasi berbagai sampel akan bervariasi sesuai dengan karakteristik sampel terutama karakteristik antioksidan sampel (Molyneux, 2004).

Hasil uji aktivitas antioksidan dapat dilihat pada Tabel 3. Hasil pengujian masingmasing sampel, memiliki perbedaan yang signifikan satu terhadap yang lain $(\mathrm{p}=0,000)$ pada uji one way ANOVA dan LSD. Fraksi etanol-air memiliki nilai rata-rata $\mathrm{IC}_{50}$ yang paling kecil yang berarti memiliki aktivitas antioksidan terbesar yaitu $9,090 \mu \mathrm{g} / \mathrm{mL} \pm$ 0,122 , diikuti fraksi etil asetat $11,875 \mu \mathrm{g} / \mathrm{mL}$ $\pm 0,038$, kemudian ekstrak etanol herba apuapu $16,675 \mu \mathrm{g} / \mathrm{mL} \pm 0,239$, sedangkan fraksi n-heksana menunjukan nilai $\mathrm{IC}_{50}$ terbesar, dengan aktivitas antioksidan terkecil yaitu $29,915 \mu \mathrm{g} / \mathrm{mL} \pm 0,156$. Ekstrak dan fraksinya menunjukan aktivitas antioksidan yang lebih kecil daripada vitamin $\mathrm{C}$ dengan $\mathrm{IC}_{50}$ sebesar $3,263 \mu \mathrm{g} / \mathrm{mL} \pm 0,032$.

Menurut Phongpaichit et al., 2007, suatu senyawa dinyatakan sebagai antiradikal bebas sangat kuat apabila nilai $\mathrm{IC}_{50}<10 \mu \mathrm{g} / \mathrm{mL}$, kuat apabila nilai $\mathrm{IC}_{50}$ antara $10-50 \mu \mathrm{g} / \mathrm{mL}$, sedang apabila nilai IC $_{50}$ berkisar antara 50-100 $\mu \mathrm{g} /$ $\mathrm{mL}$, lemah apabila nilai $\mathrm{IC}_{50}$ berkisar antara $100-250 \mu \mathrm{g} / \mathrm{mL}$ dan tidak aktif apabila $\mathrm{IC}_{50}$ diatas $250 \mu \mathrm{g} / \mathrm{mL}$. Berdasarkan nilai $\mathrm{IC}_{50}$ masing-masing sampel menunjukkan bahwa secara umum seluruh sampel mempunyai aktivitas antioksidan sangat kuat untuk fraksi

Tabel 3. Hasil Uji Aktivitas Antioksidan Ekstrak Etanol Herba Apu-Apu dan Fraksi-

\section{Fraksinya}

\begin{tabular}{lcc}
\hline \multicolumn{1}{c}{ Sampel } & $\begin{array}{c}\text { Rata-rata } \mathrm{IC}_{50} \\
(\mu \mathrm{g} / \mathrm{mL}) \pm \mathrm{SD}\end{array}$ & $\begin{array}{c}\text { Daya } \\
\text { antioksidan }\end{array}$ \\
\hline Ekstrak Etanol & $16,675 \pm 0,239^{\mathrm{a}}$ & Kuat \\
Fraksi N-heksana & $29,915 \pm 0,156^{\mathrm{b}}$ & Kuat \\
Fraksi Etil asetat & $11,875 \pm 0,038^{\mathrm{c}}$ & Kuat \\
Fraksi Etanol-air & $9,090 \pm 0,122^{\mathrm{d}}$ & Sangat Kuat \\
Vitamin C & $3,263 \pm 0,032^{\mathrm{e}}$ & Sangat Kuat \\
\hline
\end{tabular}

Keterangan: Notasi huruf yang berbeda menunjukkan adanya perbedaan yang signifikan antar kelompok $(p<0,05)$ 
etanol-air, dan kuat untuk ekstrak etanol herba apu-apu dan fraksi lainnya.

Salah satu golongan senyawa aktif yang diduga berperan dalam memberikan aktivitas antioksidan pada ekstrak etanol herba apu-apu dan fraksi-fraksinya adalah golongan polifenol. Senyawa polifenol mempunyai kemampuan untuk menyumbangkan atom hidrogen kepada senyawa radikal bebas, maka aktivitas antioksidan senyawa polifenol dapat dihasilkan pada reaksi netralisasi radikal bebas atau pada penghentian reaksi berantai yang terjadi (Yuhernita \& Juniarti, 2011).

\section{KESIMPULAN}

Kesimpulan dari penelitian ini adalah ekstrak etanol herba apu-apu dan fraksi-fraksinya memiliki aktivitas antioksidan ekstrak etanol herba apu-apu dan fraksi-fraksinya memiliki aktivitas antioksidan, yaitu dari yang tinggi ke rendah secara berurutan : fraksi etanol-air, fraksi etil asetat, ekstrak etanol herba apu-apu, fraksi n-heksana.

\section{UCAPAN TERIMA KASIH}

Penelitian ini didanai oleh DIPA UNEJ Tahun 2019.

\section{Daftar Pustaka}

Badarinath, A., Rao, K., Chetty, C. S., Ramkanth, S., Rajan, T,, \& Gnanaprakash, K. 2010. A Review on In-vitro Antioxidant Methods: Comparisons, Correlations, and Considerations. International Journal of PharmTech Research. 1276-1285.

Depkes RI. 2000. Parameter Standar Umum Ekstrak Tumbuhan Obat (Edisi 1). Jakarta: Direktorat Jenderal Pengawasan Obat dan Makanan, Direktorat Pengawasan Obat Tradisional.

Edawati, Z. 2012. Uji Aktivitas Antioksidan Ekstrak Metanol Ascidia Didemnum sp. Dari Kepulauan Seribu dengan Metode 1,1-Difenil-2 Pikrilhidrazil (DPPH) dan Identifikasi Golongan Senyawa dari Fraksi Teraktif. Skripsi. FMIPA UI: Depok.

Halliwell, B. \& Gutteridge, J. M. C. 2000. Free Radical in Biology and Medicine. Newyork: Oxford University Press.

Ito, N., M. Hirose, S. Fukishima, H. Tsada, T. Shirai, \& M. Ttematsu. 1986. Studies on Antioxidants: Their Anticarcinogenic and Modifying, Effects on Chemichal Carcinogenesis. Food Chem. Toxico.l, (24):1099-1102.

Khan, M.A. et al. 2014. Pistia stratiotes L. (Araceae) : Phytochemistry, Use In Medicines, Phytoremediation, Biogas, and Management Options. Pak. J. Bot., 46(3): 851-860.

Khare, C.P. 2005. Encyclopedia of Indian medicinal plants. Berlin Heidelberg, Germany: Springer-Verlag.

Kumalaningsih, S., 2006. Antioksidan Alami. Surabaya: Trubus Agrisarana.

Kumar, H.K.S., M.B.V. Raju, S.C. Dinda, S. K. Sahu \& M. Banerjee. 2011. Analgesic, antiinflammatory and antipyretic activity of Pistia stratiotes L. Rasayan J. Chem., 4(3): 506511. 
Marinova, D., Ribanova, F., Atanassova, M. 2005. Total Phenolics and Total Flavonoids in Bulgarian Fruits and Vegetables. Journal of the University of Chemical Technology and Metallurgy, (40): 255-260.

Molyneux, P. 2004. The Use of Stable Free Radical Diphenylpicryl hydrazyl (DPPH) for estimating antioxidant activity. Songklanakarin J. Sci. Technol, 26(2): 211-219.

Pallavi, T., S. Arora, R. Gupta \& P. Mali. 2011. Diuretic activity of Pistia stratiotes leaf extract in rats. Int. J. of Pharmacy, 2(3): 249-251.

Phongpaichit, S., et al. 2007. Biological Activities of Extracts From Endophytic Fungi Isolated From Garcinia Plant. FEMS Immunology \& Medical Microbiology, 51(3), 517 - 525.

Yuhernita \& Juniarti. (2011). Analisis Senyawa Metabolit Sekunder dari Ekstrak Metanol Daun Surian yang berpotensi Sebagai Antioksidan. Makara Sains, 15(1), 48 - 52. 